\title{
НЕКРАСОВ И БОРАТЫНСКИЙ: \\ ВОКРУГ РЕЦЕНЗИИ НА «ДАМСКИЙ АЛЬБОМ», НОВЫХ ВЗГЛЯДОВ НА БРАК И ДВУХ ЛЮБОВНЫХ СТИХОТВОРЕНИЙ
}

\author{
П. Ф. Успенский \\ (Москва)
}

Стихотворения Е. А. Боратынского практически никогда не воспринимались литературоведами как потенциальный фактор влияния на зрелую поэтику Н. А. Некрасова. Подобная точка зрения закономерна: Боратынский - во многом благодаря взглядам В. Г. Белинского - не перешел в послепушкинскую эпоху как значимое литературное явление ${ }^{2}$. Несмотря на ряд изданий, способствующих популяризации наследия Боратынского (подборка стихов в № 1 «Современника» за 1854 г., отдельное издание его стихов 1869 г.), до эпохи символизма поэт не был канонизирован в литературном поле (см.: Винокур 2002; Гельфонд 2012, с указанием литературы).

1 Автор признателен М. С. Макееву, М. Ю. Степиной, А. М. Березкину и А. С. Бодровой, с которыми обсуждалась данная работа. Статья подготовлена в рамках гранта РГНФ, проект 16-34-01060 (а2).

2 Впрочем, отношение Белинского к поэту пушкинской поры было не столь однозначным: хотя он весьма критично отнесся к антипрогрессивным и пессимистичным стихам Боратынского, критик все же оценил дарование поэта и восхитился некоторыми «удивительными стихотворениями». Не имея возможности подробно описывать отношения Белинского к Боратынскому, сошлемся на ряд работ: Венгеров 1904: 626-637; Иванов-Разумник 1916; Баратынский 1936, 1: 354, 357; Гинзбург 1997: 83-87.

Приведем также остроумное замечание С. А. Венгерова, согласно которому «именно Белинский-то и создал Баратынскому крупную литературную репутацию» (Венгеров 1904: 634). Едва ли соображения о «крупной литературной репутации» справедливы, однако с учетом важности мыслей Белинского для современников и следующих поколений стоит признать, что фоновое присутствие Боратынского как неактуального поэта в литературном пространстве второй половины XIX в., возможно, способствовало его канонизации символистами. 
Некрасов с его пристальным вниманием к поэзии первой трети XIX в., очевидно, интересовался поэтом больше менники, считавшие, что Боратынский, «темный и неразвившийся, стал себя выказывать людям и сделался чрез то для всех чужим и никому не близким» (Гоголь 1952: 385-386), а к тому же был еще, по словам В. П. Боткина, и «пьяницей» (Некрасов 1981-2001, 14. 195). Об этом интересе свидетельствуют не только упоминания Боратынского в прозе и критике, но и тот факт, что в ранних стихах Некрасова периода сборника «Мечты и звуки», в таких стихотворениях как «Встреча душ», «Горы», «Час Молитвы», «Сердцу» (1839), не раз находили отзвуки поэзии Боратынского (см.: Некрасов 1981-2001, 1: 651, 653, 661, 662).

Более интересными представляются случаи влияния Боратынского на зрелое самостоятельное творчество Некрасова. Эта историко-литературная проблема практически не рассматривалась, и мы можем упомянуть лишь несколько сделанных наблюдений. Так, критик «Отечественных записок» полагал, что «Муза» (1852) Некрасова «напоминает <...> отчасти» стихотворение Боратынского «Не ослеплен я музою моею...» (Отечественные записки 1854, IV: $39)^{4}$. А. М. Березкин отмечал, что «Уныние» Некрасова (1874) восходит к традиции русской элегии первой половины XIX в. и несет на себе влияние «Осени» Боратынского 5 . По мнению того же исследователя, отраженная во «Вступлении к песням 1876-77 годов» тема преодоления страданий тела «могучей силой вдохновенья» может быть преемственно связана со стихотворением Боратынского «Болящий дух врачует песнопенье...»; Некрасов развивает исходный тезис - для него «творчество способно стать средством преодоления не только душевных, но и физических страданий» (Березкин 2008: 27). К этим наблюдениям стоит добавить, что, работая над

\footnotetext{
3 Стоит отметить, что в библиотеке Некрасова была книга «Стихотворения Евгения Баратынского» (М., 1835) - экземпляр с надписью: «И. Панаев» (Литературное наследство 1949: 367-368).

4 По-видимому, статья принадлежит перу С. С. Дудышкина. Выражаем признательность А. М. Березкину за указание предполагаемого автора. См. также: Летопись жизни Некрасова 2006: 434.
}

5 Доклад в МГУ на Некрасововедческом семинаре МГУ-ИРЛИ 16 апреля 2010 г. 
поэмой о М. Н. Волконской, Некрасов выписал для себя первые четыре строки из стихотворения Боратынского «Княгине 3. А. Волконской» (см.: Мельгунов 1980: 192).

К этому небольшому списку мы можем добавить еще одно наблюдение. Мы бы хотели обратить внимание на послание Некрасова «<А. Е. Мартынову»» (1859), которое начинается как вариация стихотворения поэта пушкинской поры:

Со славою прошел ты полдороги, Полпоприща ты доблестно свершил, Мы молим одного: чтоб даровали боги Тебе надолго крепость сил.

(Некрасов 1981-2001, 2: 51)

Сквозь приведенные строки просвечивает известнейшее стихотворение Боратынского:

Желанье счастия в меня вдохнули боги:

Я требовал его от неба и Земли

И вслед за призраком, манящим издали,

Жизнь перешел до полдороги.

(Боратынский 2002: 40)

В стихах Некрасова и усеченная четвертая строка (Я4), и рифма «боги» - «полдороги», и семантика половины жизненного пути (восходящая к началу «Божественной комедии» Данте) однозначно указывают на влияние Боратынского. Более того, некрасовское «полпоприща», по-видимому, являются семантическим развитием финала стихов Боратынского: «Отныне с рубежа на поприще гляжу / И скромно кланяюсь прохожим» (Боратынский 2002: 40).

Обратимся теперь к прозаическому наследию Некрасова. В нем высказываний о Боратынском также немного. Если в «Петербургских дачах и окрестностях» (1844) поэт только иронично перифразировал строку из стихотворения «На смерть Гёте» (Некрасов 1981-2001, 12: 94, 402) , то в атрибутированной Некрасову

6 Подчеркнем, что это стихотворение было отмечено Белинским как замечательное: Белинский 1953-1959, 1: 325. 
рецензии того же года «Учебная книга русской словесности или избранные места из русских писателей в прозе и стихах <..> изданная Н. Гречем» автор уже иронизирует над характеристиками поэта, данными в книге:

Баратынский известен небольшими романтическими поэмами и стихотворениями лирическими, в которых выражается нежное чувство изящными стихами»... Нежное чувство?.. Итак, Баратынский - поэт нежного чувства?.. А мы, признаемся, считали его поэтом мысли, преимущественно перед многими русскими поэтами. Как же мы ошибались!.. Вот точно так же ошибаемся мы, должно быть, и в князе Шаликове, почитая его поэтом нежного чувства: вероятно он-то и есть поэт мысли, поэт думы пытливой и глубокой, беспрестанно силившейся высказаться и не на минуту не покидавшей поэта! (Некрасов 1981-2001, 12, 59; 308)

В 1850 г. в письме Некрасова к А. Н. Майкову, в котором содержится предложение «написать о каком-нибудь поэте», Боратынский перечисляется через запятую наряду с В. Г. Бенедиктовым, Н. М. Языковым, А. А. Дельвигом и А. И. Подолинским (см.: Некрасов 1981-2001, 15 : 136). Несомненно, это отражает интерес Некрасова к поэзии первой трети XIX в. и свидетельствует о желании оценить роль в литературе «русских второстепенных поэтов».

Важная роль отведена Боратынскому в рецензии Некрасова на «Дамский альбом» («Современник». 1854. № 1; см. ниже). Наконец, нельзя не обратиться к уже упомянутой подборке стихов Боратынского в некрасовском журнале (1854. № 10). Публикация продолжала ряд статей «Современника», посвященных забытым поэтам, и способствовала новому осмыслению поэтического наследия первой трети XIX в. Хотя основная роль в издании подборки стихов Боратынского принадлежала Тургеневу, очевидно, что ее появление не было возможно без согласия Некрасова, поддержавшего инициативу публикатора (см.: Бодрова, Велижев 2009: 119-147).

Остановимся подробнее на еще одном, вероятно, спорном случае творческого диалога Некрасова и Боратынского. 
В № 1 «Современника» за 1854 г. была опубликована рецензия без подписи, озаглавленная как «Дамский альбом, составленный из отборных страниц русской поэзии. С десятью рисунками, гравированными в Лондоне. СПб., 1854». Этот текст, написанный в конце 1853 г., был убедительно атрибутирован Некрасову (см. подробнее: Некрасов 1981-2001, 11_: 334-335). В комментариях уже отмечалось, что рецензия связана с мыслями издателя «Современника» о русских второстепенных поэтах. Саму же рецензию можно рассматривать как небольшой очерк истории русской поэзии первой половины XIX в. Однако эти темы в настоящей статье развиваться не будут; ниже мы ограничимся лишь некоторыми наблюдениями над композицией рецензии, отдавая предпочтение основному сюжету, связанному с Боратынским.

Одна из самых примечательных особенностей рецензии на «Дамский альбом» заключается в том, что в ней Некрасов целиком привел «Признание» Боратынского («Притворной нежности не требуй от меня...»; 1823, 1832-33 гг.; в статье стихотворение озаглавлено «Послание») ${ }^{7}$, а следом за этой републикацией полностью процитировал свое стихотворение - «Когда из мрака заблужденья...» $(1845)^{8}$. Текст Боратынского при этом

7 Здесь Некрасов употребляет заглавие, используемое в рецензируемой антологии Дамский альбом 1854: 129.

8 Соседство текстов отмечалось в научной литературе (см.: Некрасов 1987: 465), однако никакого объяснения этому факту еще не было дано.

Строго говоря, Некрасов цитирует свой текст не сразу после «Признания» Боратынского, а после небольшой вставки: «Это одно из лучших стихотворений Баратынского... // Таким образом, перебирая «Дамский альбом» от первой страницы его, вопрошающей: // Зрел ли ты певец Тииский... <цитируется 4 строки> до последней, на которой напечатано следующее стихотворение: // Когда из мрака заблужденья...<цит. до конца>» (Некрасов 1981-2001, 11 2 : 111-112). В данном случае мы считаем возможным пренебречь подобной вставкой: сильные смысловые позиции в статье организуются полностью процитированными текстами, а не короткими цитатами. Вообще, в третьей части статьи образуется система из четырех стихотворений: «Розы» Мятлева, «Холодное признание» Бенедиктова, «Послание» <так!> Боратынского и «Когда из мрака заблуждения...» Некрасова. Мы будем специально рассматривать только последнюю пару, а к тексту Бенедиктова обратимся ниже. Произведение Мятлева нами рассматриваться не будет. Стихотворение Некрасова, приведенное в рецензии, отличается от текста, представленного в «Дамском альбоме» (см.: Дамский альбом 
сопровождался такими комментариями: 1) до стихотворения: «Большое удовольствие доставило нам встреченное в альбоме стихотворение г. Баратынского “Послание", которое как-то прежде ускользало от нашего внимания при чтении Баратынского» и 2) после стихотворения: «Это одно из лучших стихотворений Баратынского...» (Некрасов 1981-2001, 11: 110-111).

Странное соседство двух стихотворений в рецензии ставит несколько вопросов. Почему Некрасов так высоко оценил стихотворение Боратынского? Почему «Признание» и «Когда из мрака заблужденья...» соседствуют в статье? Какие литературные цели преследовал Некрасов, публикуя два стихотворения рядом?

Самый простой и при этом верный ответ на первый вопрос заключается, по-видимому, в следующем: Некрасову понравилось «Признание» Боратынского потому, что это одна из лучших элегий в русской поэзии. Именно так ее оценил Пушкин в письме к А. А. Бестужеву (1824): «Баратынский прелесть и чудо; “Признание” совершенство. После него никогда не стану печатать своих элегий...» (Пушкин 1937: 84). Однако думается, что в любовной элегии Боратынского Некрасов мог увидеть нечто большее.

Напомним вкратце содержание «Признания». Разочарованный в любви поэт обращается к своей возлюбленной, анализируя причины любовного охлаждения: «И пламень мой, слабея постепенно, / Собою сам погас в душе моей». Заверяя возлюбленную, что он «не пленен красавицей другою», и что его душа желает любви, но вновь любить он не будет, лирический герой начинает моделировать свое будущее, представляя, как изберет себе «подругу без любви», подаст ей руку на обдуманный брак и как они соединяет «не сердца, а жребии». Избрав новый путь, поэт прощается со своей бывшей возлюбленной. Стихотворение заканчивается известной сентенцией: «Невластны мы в самих себе, / И, в молодые наши леты, / Даем поспешные обеты, / Смешные может быть всевидящей судьбе...» (Боратынский 2002: 63).

1854: 256-258). См. также: Некрасов 1981-2001, 112: 334-335. О возможных причинах изменения строфы - см. ниже. 
И. Л. Альми отмечала, что Боратынский в этом стихотворении отказывается от романтической трактовки разочарованного героя: «Перед нами точно зафиксированный процесс охлаждения чувства. Любовь погасла не из-за каких-то романтических причин <...>. Она задушена будничными обстоятельствами будничной жизни. <...> Подчеркнуто объективно рисуя картину будущего своего брака без любви, герой “Признания” ощущает себя виновным не только перед той, которую сейчас оставляет, но и перед той, “невинной, преданной, быть может, лучшим снам”, с которой в будущем соединит “жребий”, но не “сердце” (Альми 1961: 43-44).

Согласно точке зрения И. М. Семенко, «у Баратынского несчастная любовь изображена как следствие душевной изолированности людей, невозможности одному человеку понять чувства другого. Переживания каждой личности располагаются в своей особой плоскости, и эти плоскости несовмещаемы. <...> По Баратынскому, счастье невозможно, а души человеческие далеки друг от друга. Соединяются не “сердца”, а “жребии”» (Семенко 1970: 239-240).

Важно отметить, что Боратынский рассматривает и любовное разочарование, и брак без любви в свете борьбы человека с всевидящей судьбой. «Но ожидающее его спокойное будущее отнюдь не кажется ему желанным, он воспринимает возможное примирение с судьбой как полную победу судьбы, как отказ от лучшего в самом себе, как слияние с обывательской толпой» (Альми 1961: 44). Брак без любви предстает как поступок, совершенный от безысходности.

Приведенные цитаты из работ филологов отражают стремление к более или менее объективному пониманию текста. Однако едва ли мы можем полагать, что Некрасов воспринимал стихотворение Боратынского в том же ключе, что и литературоведы. Более того, думается, Некрасов в смысловом или даже идеологическом плане радикально переосмыслил некоторые строки «Признания» в силу того, что придерживался новых взглядов на любовь и институт брака. Поэтому, прежде чем вернуться непосредственно к текстам, мы должны сделать еще одно отступление, связанное с историей идей. 
К тому времени, когда Некрасов напечатал в своей рецензии стихотворение Боратынского, в обществе складывалась новая концепция любви и института брака. Как правило, рождение новых идей связывается с 1850-1860 гг., а главная роль глашатая свободных взглядов отводится Н. Г. Чернышевскому (см., например: Щукин 2002: 140-150). Ментальный феномен заключался в том, что ряд людей, чаще всего интеллигенты-разночинцы, стали воспринимать любовь более реалистично и рационализованно. При этом нас будет интересовать именно их восприятие, т. е. мы не будем задаваться вопросом, насколько эти новые идеи идеалистичны или романтичны по своей сути. Рассматриваемому явлению посвящена монография И. А. Паперно (см.: Паперно 1996), и далее мы будем в основном опираться на ее монографию.

В новом понимании любовных отношений 9 можно выделить две тенденции, которые, конечно, переплетались между собой: № 1) стремление к свободным формам любви, которое привело к возникновению нескольких тройственных союзов (среди которых видное место занимает треугольник, сформированный И. И. Панаевым, А. Я. Панаевой и Некрасовым $)^{10}$.

Другая тенденция (№ 2) заключалась в изменении представлений о браке по расчету. В. Г. Белинский еще в 1838 г. писал М. А. Бакунину:

9 Напомним, что новые воззрения на отношения между полами вызваны, по-видимому, отталкиванием от взглядов на возвышенную любовь в философских кружках 30-х гг. XIX в., в том числе - в кружке Станкевича, и увлечением взглядами Жорж Санд (см.: Паперно 1996: 54-58; Щукин 2002: 141-142).

10 Здесь уместно упомянуть сложные взаимоотношения А. И. Герцена, его жены Наталии Александровны и немецкого поэта Г. Гервега, причем, инициатором тройственного союза и носителем новых идей оказалась Наталия Александровна. Через несколько лет в жизни Герцена любовный треугольник повторился: Герцен - Н. А. Тучкова-Огарева - Н. П. Огарев. Однако если в конце 1840-х - начале 1850 -х гг. Герцен скорее отрицал новую идеологию, во всяком случае, применительно к себе и своей жене, то во второй половине 1850-х гг. он сам становится носителем новых идей. См., впрочем, письмо Герцена Огареву конца 1856 г.: Герцен 1954-1965, 26: 62-63. Можно упомянуть и любовный треугольник, образованный Н. В. Шелгуновым, Л. П. Шелгуновой и М. И. Михайловым (см.: Паперно 1996: 125-127). 
Идеальный человек, не встречая нигде своей идеальной женщины, потому что ее нигде нет, приходит в отчаяние и уверяется, что грязная и пошлая действительность есть истинная действительность. <...> Обыкновенно он женится на судомойной тряпке, и часто еще без всяких выгод для обеспечения жизни; $<\ldots>$ Он не понимал действительности, не понимал, что не всем суждено любить (т.е. влюбиться), быть любимым и жениться по любви, $<\ldots>$ но он не понимал и того, что выход есть совсем не противоположность, что, кроме пошлого расчета, есть еще расчет человеческий, имеющий в виду удовлетворение лучшей стороны своей человеческой природы, что рассудок не есть единственный выход из состояния чувств, но что то и другое может действовать в ладу, не мешая одно другому (Белинский 1953-1959, 11: 286).

Обратим внимание, что, не отрицая случаев брака, вызванных к жизни лишь умственными построениями, критик предлагает на его взгляд - новый путь, который оказался продуктивным для целого ряда интеллектуалов.

И. Паперно отмечает, что «брак по расчету (не имевший ничего общего с материальной выгодой) был сознательной и желательной позицией, лишенной отрицательных коннотаций» (Паперно 1996: 93). Он часто совершался для избавления женщины от тирании родителей (в таком случае брак обеспечивал свободу слабому полу) или же для спасения женщины падшей (по-видимому, помимо идеи спасения тут проявлялась также идея воспитания и развития) ${ }^{11}$. Повидимому, в этом же ключе можно воспринимать совместную жизнь Некрасова с Зинаидой Николаевной (Ф. А. Викторовой): согласно ряду источников, род ее занятий до знакомства с поэтом не вызывает сомнений; Некрасов же, в свою очередь, старался ее просвещать; венчание, состоявшееся незадолго до смерти поэта, по-видимому, мотивируется его желанием обеспечить возлюбленной дальнейшее

11 Так, например, мотивацией брака Чернышевского (1853г.) было спасение репутации Ольги Сократовны. В свете указанной тенденции можно воспринимать увлечение Добролюбова Терезой Карловной Гринвальд и намерение поэта жениться на ней. См. о цикле любовных стихотворений в связи с этим увлечением: Вдовин 2007: $74-88$. 
существование и укрепить ее статус, поскольку в окружении Некрасова Зинаида Николаевна имела не самую лучшую репутацию (см.: Степина, в печати).

Таким образом, и биография Некрасова, и жизненные обстоятельства его современников, позволяют сделать вывод, что поэт также был носителем новых взглядов на любовь и на институт брака. В свете этого мы можем считать, что ключевыми для Некрасова оказались следующие строки из «Признания» Боратынского:

Кто знает? мнением сольюся я с толпой;

Подругу, без любви, кто знает? изберу я.

На брак обдуманный я руку ей подам

И в храме стану рядом с нею

Невинной, преданной быть может лучшим снам,

И назову ее моею,

И весть к тебе придет; но не завидуй нам:

Обмена тайных дум не будет между нами,

Душевным прихотям мы воли не дадим:

Мы не сердца под брачными венцами,

Мы жребии свои соединим...

Прощай. Мы долго шли дорогою одною:

Путь новый я избрал, путь новый избери...

(Боратынский 2002: 62-63)

Эти строки, скорее всего, были не только оценены с эстетической точки зрения, но и кардинально переосмыслены: вероятно, подобный сценарий не воспринимался Некрасовым как негативный, а, согласно новому взгляду на институт брака, виделся скорее жизнеобещающим, если не сказать - желательным. В самом деле, идея соединения жребиев, а не сердец соответствовала новым представлениям о браке, и предпочтение сердца жребию Боратынским в восприятии Некрасова могло полностью перевернуться в пользу жребия.

По-видимому, важными для Некрасова были строки, в которых поэт обращался к своей возлюбленной: «Путь новый я избрал, путь новый избери; / Печаль бесплодную рассудком усмири...». 
Действительно, в этих словах Боратынского видна некоторая неоднозначность: с одной стороны, все стихотворение посвящено тому, как лирический герой мысленно сливается «мнением с толпой», совершает в уме поступок, являющийся полной победой судьбы над человеком. С другой стороны, гипотетическое будущее, описанное в этих строках, предстает как сознательно выбранный путь, причем само слово «путь», связанное скорее с идеей миссии, как бы легализует подобный проект будущего, дает ему право на существование и воплощение. Характерна, как кажется, и апелляция именно к рассудку у Боратынского: смоделированное героем будущее является плодом ума, интеллектуальным построением, и именно рациональной оценки ситуации герой требует от своей возлюбленной. Как мы видим, текст Боратынского даже при попытке более или менее объективного прочтения содержит в себе смысловую неоднозначность. Для Некрасова же, по-видимому, она трактовалась в пользу его идеологии.

В приведенном выше фрагменте элегии есть место, противоречащее новой концепции любви. Это строка, описывающая невесту: «невинная, преданная, быть может, лучшим снам». Противоречит новым представлениям и предостережение Боратынского - «Но не завидуй нам!». Думается, однако, что в данном случае общая модель была важнее частностей, и при важности общей темы подобные противоречащие смысловые элементы могли игнорироваться. Мы полагаем, таким образом, что Некрасов воспринял это стихотворение как поэтизацию брака по расчету, придав ему современное значение.

Итак, помимо того, что «Признание» - замечательные стихи, Некрасов, радикально их переосмыслив, увидел в них созвучные настроения и идеи и воспринял их как своеобразный манифест, написанный еще в пушкинскую эпоху ${ }^{12}$.

12 Соответственно, в восприятии элегии произошел, по всей вероятности, очень сильный смысловой сдвиг. Если у Боратынского «брак обдуманный» - это норма, то, что приписывает человеку «толпа», то для «новых людей» брак по расчету - это, наоборот, вызов общепринятым социальным нормам. 
В свете сказанного легко объяснить тот факт, что «Признание» и «Когда из мрака заблуждения...» непосредственно соседствуют в статье. Стихотворение Некрасова как будто тематически продолжает элегию поэта пушкинской поры, но продолжает не так, как понимал ее сам Боратынский, а так, как она, вероятно, была прочитана Некрасовым - как позитивная жизненная программа.

«Когда из мрака заблужденья...» также является обращением, но уже к падшей женщине с предложением стать «хозяйкой» в доме лирического героя. Важно, что в стихах Некрасова ни слова не говорится о любви, поэт поддерживает падшую женщину участием и, пользуясь словами Боратынского, призывает «соединить их жребии». Некрасов говорит о темном прошлом героини, которую опутал порок; по сути, она не виновата в происходящем, лирический герой обращается к ней «дитя несчастья!» и приписывает ей «болезненно-пугливую душу» (прилагательное «пугливая» как характеристика души возлюбленной близко по значению к слову «невинная», как характеризует Боратынский свою гипотетическую жену). В некрасовском тексте вина возлагается на толпу, которая убеждает женщину, что она пала: «Толпы бессмысленному мненью / Ужель и ты покорена?». Лирический герой частично разделяет точку зрения социума, когда в шестой строке произносит слово «порок» («Тебя опутавший порок...»; ср.: «Кто знает? Мнением сольюся я с толпой...»), но рассказ героини убеждает его в невиновности женщины.

Стихотворения, конечно, не похожи. Но при всем их различии, в сознании Некрасова они могли объединяться как тексты, поэтизирующие новые представления о любви. Их соседство в статье заставляет читателя увидеть в них нечто общее. Публикуя их рядом, Некрасов создает такой контекст для своего стихотворения, что мы (как и читатели «Современника») должны читать «Когда из мрака заблужденья...» в свете текста Боратынского. Стихотворение Некрасова предстает, в таком случае, как развитие и углубление элегии поэта пушкинской поры. В «Когда из мрака заблужденья...» опускается тема брака, что, по-видимому, объясняется новым мировоззрением: в свободных формах любви в браке нет специаль- 
ной надобности, за исключением случаев спасения женщины. Однако в некрасовском тексте имплицитно присутствует идея объединения судеб (жребиев) героев. Поэт идет дальше Боратынского: если автор «Признания» поэтизирует, в общем-то, распространенную жизненную модель, обогащая ее рефлексией и тем самым как бы легализуя ее, то Некрасов для основной темы стихотворения выбирает уже нетривиальные жизненные обстоятельства. «Невинная и преданная лучшим снам» героиня Боратынского превращается в другом стихотворении в женщину с порочным прошлым, жертву обстоятельств, сохранившую при этом чистую душу.

В связи с этим представляет интерес тот факт, что Некрасов в рецензии не просто перепечатал текст своего стихотворения, но внес изменения в 4-ю строфу. В «Дамском альбоме» мы читаем: «Я разделял твои мученья, / Я горячо тебя любил, / И жалкой мыслью отчужденья, / Клянусь, на миг не оскорбил!..» (Дамский альбом 1854: $257)^{13}$. В рецензии же эти строки были заменены следующими: «Мне луч божественный участья / Весь темный путь твой осветил. / Я понял всё, дитя несчастья, / Я всё простил и позабыл!» (Некрасов 1981-2001, 11 : 112). Очевидно, что в новом варианте Некрасов отказывается от темы любви и допускает большую эмоциональную дистанцированность: если в тексте «Дамского альбома» поэт употребляет лишь лексику, связанную со сферой чувств, то в тексте рецензии он моделирует интеллектуальное осознание происходящего, а акцент переносится с разделения чувств на понимание. Думается, что изменение строфы могло быть напрямую связано с текстом Боратынского, точнее, с желанием создать единое смысловое поле обсуждаемых стихотворений: слова о любви из предыдущего варианта звучали бы в контексте «Признания» диссонансом и выстраивали бы другое соотношение текстов, в котором Боратынский не воспринимался бы как важный поэт, который еще в свое время «предвосхитил» актуальные в эпоху Некрасова жизненные сценарии.

13 См. не вполне точное воспроизведение этих строк: вместо «И жалкой мыслью»«Но жалкой мыслью» (Некрасов 1981-2001, 12: 334). 
Итак, по мысли поэта, «Когда из мрака заблужденья...» должно было читаться в контексте стихотворения Боратынского. Дополнительное тому доказательство - приведенное перед текстом «Притворной нежности не требуй от меня...» и высоко оцененное Некрасовым «Холодное признание» Бенедиктова. Это стихотворение тематически связано с произведением Боратынского. Оно также является обращением к возлюбленной и в нем идет речь об охлаждении чувства. В фокусе «Холодного признания» мы видим ту же ситуацию любовного разочарования, однако, в отличие от психологического анализа Боратынского, она связывается лишь со взрослением героя («Я пережил дней юношеских жар») и описывается скорее набором метафорических оппозиций.

Примечательно, что написанное позже стихотворение Бенедиктова (1837) в рецензии предшествует тексту Боратынского. Это можно объяснить внутренней логикой статьи, однако нельзя не отметить, что подобная последовательность текстов и связывает их между собой, и выделяет «Притворной нежности не требуй от меня...» как стихи, принципиально по-другому разрешающие ситуацию охлаждения чувства ${ }^{14}$.

Вторгаясь в область психологических объяснений, любопытно предположить, что именно спровоцировало Некрасова сопоставить в рецензии свое стихотворение с элегией Боратынского. Если верить воспоминаниям А. В. Дружинина, вскоре после выхода «Дамского альбома...» на квартире Некрасова собрались литераторы -

Один из них с наслаждением прочитал стихи, о которых говорится <«Когда из мрака заблужденья...». - П. У.>. Другой подивился тому, как могла эта прелестная вещь до сих пор оставаться в неизвестности, третий осведомился об имени автора, четвертый

\footnotetext{
14 Нам можно возразить, что последовательность текстов вызвана их расположением в «Дамском альбоме». Действительно, стихи Бенедиктова напечатаны прежде стихов Боратынского (Дамский альбом 1854: 68-69, 129-131). Думается, однако, что в данном случае расположение стихов в книге соответствовало замыслу рецензента. Отметим, что вариант стихов Бенедиктова в «Дамском альбоме» сильно отличается от канонического. См.: Бенедиктов 1939: 64. Подробное текстологическое сопоставление текстов не входит в задачу настоящей статьи.
} 
сказал: «Таких стихов не может написать никто, кроме Пушкина». Тогда только сам автор, налицо находившийся в комнате, поблагодарил друзей своих за похвалу и внимание. Конечно, похвала, до такой степени непредвиденная и неподготовленная, имеет свою сладость, но мы не ручаемся в том, что г. Некрасов, даже под влиянием понятного удовлетворения, в глубине души не упрекнул своих товарищей за всю случайность их позднего одобрения (Дружинин 1987: 261).

Если этот эпизод действительно произошел (в нем вызывает некоторое сомнение незнание имени автора стихотворения, тогда как некрасовский текст впервые был напечатан в № 4 «Отечественных записок» за 1846 г.), то очень соблазнительно предположить зависимость между разговором в гостиной и текстом рецензии (комплименты, уравнивающее поэтическое мастерство Пушкина и Некрасова, могли повлиять на литературное самосознание Некрасова и подтолкнуть его к публичному, но не прямому, сопоставлению своего творчества с поэзией первой трети XIX в.).

Впрочем, нельзя исключать вероятности того, что, сочиняя «Когда из мрака заблуждения...», Некрасов уже ориентировался на пушкинскую эпоху. Для допущения такой мысли достаточно предположить, что, сопоставляя в тексте рецензии свое стихотворение и элегию Боратынского, Некрасов прямо назвал источник «Когда из мрака заблужденья...». Иными словами, достаточно предположить, что связь между двумя стихотворениями возникла не во время чтения «Дамского альбома» и работы поэта над рецензией, а значительно раньше, в момент сочинения «Когда из мрака заблужденья...» (в рецензии же, в таком случае, связь текстов была только проговорена).

В самом деле, необходимо обратить внимание на комментарии младшего поэта. Согласно его свидетельству, «Притворной нежности не требуй от меня...» он раньше не знал, точнее - это стихотворение «как-то прежде ускользало от нашего внимания при чтении Баратынского». Между тем, маловероятно, что Некрасов не читал или не знал этих стихов: «Признание» - одна из самых известных элегий Боратынского. Она была напечатана и в собрании 
стихов 1835 г. (которое было в библиотеке Некрасова), и в «Дамском альбоме» 1844 г. Неопределенность первого некрасовского комментария («как-то <..> ускользало»), который не согласуется с категоричностью второго - «Это одно из лучших стихотворений Баратынского» - позволяет усомниться в словах Некрасова, который в раннем творчестве испытал влияние как Боратынского, так и других поэтов первой половины XIX в. Скорее всего, «Признание» он знал ${ }^{15}$.

Некрасов мог прочитать стихотворение Боратынского и осмыслить его приблизительно так, как мы пытались реконструировать, значительно раньше, чем в конце 1853 г. В таком случае, мы можем предположить, что обсуждаемая нами преемственность стихотворения «Когда из мрака заблужденья...» по отношению к «Притворной нежности не требуй от меня...» не была сконструирована Некрасовым во время написания рецензии, а возникла за несколько лет до этого, около 1845 г., когда и было сочинено некрасовское стихотворение.

Действительно, в это время, как следует хотя бы из текста обсуждаемого стихотворения, Некрасов уже разделял новые взгляды на любовные отношения. Как показала в одном из докладов М. Ю. Степина, текст «Когда из мрака заблужденья...» имеет биографический подтекст и, по-видимому, связан с А. Я. Панаевой (Софийская 2010: 267-268). Отрицание традиционного института брака и увлечение новыми веяньями могло прийти к поэту от Белинского, который, как уже отмечалось, в вопросе о браке по расчету считал, что «кроме пошлого расчета есть еще расчет человеческий, имеющий в виду удовлетворение лучшей стороны своей человеческой природы» (Белинский 1953-1959, 11: 286).

Необходимо упомянуть несколько конкретных историй, обсуждавшихся в обществе и, вероятно, некоторым образом повлиявших на концепцию стихотворения «Когда из мрака заблужденья...». Это, прежде всего, любовная связь Н. Х. Кетчера с далекой

15 Кажется, нашу гипотезу подтверждает тот факт, что это стихотворение в рецензии на «Стихотворения» Боратынского было выделено Белинским как «замечательное» (что, скорее всего, было известно Некрасову); см.: Белинский 1953-1959, 1: 325. 
от культуры девушкой-сиротой, воспитанницей старообрядческого скита, ярко описанная в «Былом и думах» (см.: Герцен 1954-1965, 9: 234-237); ср.: Некрасов 1987: 465). Возможно, первая жена Огарева в некоторой степени разделяла новые взгляды ${ }^{16}$. В данном случае мы можем говорить и о браке Белинского (1843 г.). П. В. Анненков вспоминал: «Женившись, Белинский не отказался, однако ж, от своих воззрений на сродство душ и стремлений как на единственный элемент, узаконяющий брачное состояние, и сознавался, что в его собственном браке недоставало идеального повода и отсутствовало поэтическое настроение. Он высказывал это мнение, не стесняясь, и перед всеми громко и часто...» (Анненков 1989: 341342; Щукин 2002: 142).

Важно, что некоторые современники не различали конкретных носителей новых мнений и рассматривали их как социальный круг во главе с известным критиком: «...Все общество пропитано какимто ребячески циническим взглядом на семью и на отношения к женщине - которым хвастают, в главе стоит Белинский, но в нем цинизм уж не ребячество и имеет глубокий смысл. Это общество издает “Современник” (Письмо А. А. Бакунина П. А. Бакунину от 3 марта 1847 г.; Литературное наследство 1950: 188). Ср. также взгляд изнутри писательского сообщества: «писатели высказывали большое сочувствие к женскому вопросу тем, что старались опоэтизировать падших женщин, “Магдалин XIX века”, как они выражались» (Панаева 1986: 114). Биографические обстоятельства Некрасова 1840-х гг. в таком случае являются вариацией общего идеологического сдвига.

Как кажется, в этом контексте предположение, что Некрасов еще в середине 1840-х. гг. воспринял стихи Боратынского в искаженной перспективе, не лишено оснований. В таком случае, возможно, что

16 См. аккуратное свидетельство Герцена: «Ее растрепанные мысли, бессвязно взятые из романов Ж. Санда, из наших разговоров, никогда ни в чем не дошедшие до ясности, вели ее от одной нелепости к другой, к эксцентричностям, которые она принимала за оригинальную самобытность, к тому женскому освобождению, в силу которого они отрицают из существующего и принятого на выбор, что им не нравится, сохраняя упорно все остальное» (Герцен 1954-1965, 9: 14-15). О предвзятости по отношению к М. Л. Огаревой см.: Герцен 1954-1965, 2: по ук. 
прочитанное и переосмысленное в свете новых идей стихотворение Боратынского не только было высоко оценено Некрасовым раньше, но и повлияло на замысел стихотворения «Когда из мрака заблужденья...».

Влияние, конечно, было непрямым, как мы видим, в тексте нет словесных перекличек и реминисценций. Но элегия Боратынского могла послужить Некрасову примером поэтизации «непоэтической темы». Вполне вероятно, что, сочиняя «Когда из мрака заблужденья...», Некрасов держал в голове «Признание» Боратынского и воспринимал этот текст как своего рода поэтический прецедент, отразивший (или предвосхитивший) новые идеологические сдвиги.

Здесь, конечно, надо указать, что стихотворение Некрасова, хотя и имеет некоторый биографический подтекст, все же достаточно условно и напрямую с биографией поэта не связано. Точнее было бы сказать, что жизненные обстоятельства поэта индуцировали появление «Когда из мрака заблужденья...», стихотворения, в котором Некрасов старался отразить новую идеологию любви. Соответственно, речь не идет о браке с Панаевой и о том, что гипотетические представления об этом браке были каким-нибудь образом связаны с переосмысленными стихами Боратынского; речь идет исключительно о том, что, если Некрасов уже в середине 1840-х гг. осмыслял элегию Боратынского в новом ключе, то и «Когда из мрака заблужденья...» он мог воспринимать как развитие и углубление «Признания». Таким образом, в свете всего сказанного, мы бы хотели предположить, что «Притворной нежности не требуй от меня...» является одним из источников стихотворения «Когда из мрака заблужденья...»" ${ }^{17}$.

\footnotetext{
17 Исходный вариант 4-й строфы, приведенный выше, в некоторой степени уменьшает правомерность подобной гипотезы. Однако думается, что, несмотря на то, что изначально Некрасов моделирует сильную эмоциональную включенность героя в лирическую ситуацию, мы не должны забывать о поэтизации непоэтической темы в целом. Общий замысел «Когда из мрака заблужденья...» отражает идеологические представления нового времени, в которых варьируются брак с расчетом в понимании Белинского, связь с женщиной другого социального происхождения (в том числе, и с проституткой) и тройственные союзы. Стихотворение Некрасова в
} 
Вне зависимости от того, верна наша гипотеза или нет, очевидно, что, публикуя стихотворения вместе, Некрасов преследовал определенные литературные цели. В чем они заключались? Как кажется, имеет смысл рассмотреть две противоположные версии, которые, тем не менее, могут дополнять друг друга. С одной стороны, стихотворение Некрасова является как бы финальным аккордом сконструированной в рецензии триады. «Когда из мрака заблужденья...» призвано оттенить стихи предыдущей эпохи и показать выход из проблемы, актуальной для предыдущего поэтического поколения и разрешенной в нынешнем. В таком случае, тексты Бенедиктова и Боратынского необходимы лишь для создания контраста, на фоне этих стихов «Когда из мрака заблужденья...» должно видеться тематически новаторским текстом. Автор рецензии на «Дамский альбом» наследует взглядам Белинского, сведшим на нет литературную репутацию Бенедиктова и подчас весьма критично высказывающегося о стихах Боратынского. Вообще, такое построение вполне согласуется с тенденцией рецензии разделять поэтические эпохи, однако высокая оценка стихов Боратынского кажется в таком случае не совсем мотивированной.

Думается, однако, что замысел Некрасова заключался в том, чтобы актуализировать в современной ему эпохе стихи поэта пушкинской поры. Поэт делает это не декларативно, а незаметно, с помощью нестандартного построения рецензии. На наш взгляд, аккуратные оценки Некрасова, его стремление не только оценить интересный текст, но и процитировать его целиком (как апелляция к вкусам читателей), вызваны некоторой противоречивостью его мнения: с одной стороны, он как бы находится в русле новой литературы и, в том числе, разделяет взгляды Белинского; с другой по-видимому, ценность некоторых поэтических текстов для него важнее, чем мнение «неистового Виссариона». Необходимо отметить,

первоначальном варианте комбинирует некоторые элементы указанных вариантов. Элегия Боратынского, в таком случае, все равно могла восприниматься поэтом как поэтический прецедент, поскольку заключала в себе как минимум один из элементов (обдуманный брак) нового взгляда на любовь. 
что оценки критика, хотя и были в некоторых случаях резкими, но все же содержали признание поэтических достоинств Боратынского (что, вероятно, позволяло автору рецензии на «Дамский альбом» писать о своих эстетических предпочтениях). Обсуждаемое стихотворение Боратынского критик называл «замечательным», хотя оно, с его точки зрения, оставляет такое же впечатление, «как дуновение уст на стекле зеркала: оно легко и скоропреходяще» (Белинский 1953-1959, 1: 325-326). По-видимому, для Некрасова - не столько как критика, сколько, прежде всего, как поэта - поэтический дискурс оказывается более значимым, чем критический, а стихи Боратынского - более сложными и интересными, чем было принято считать в то время.

В свете сказанного, рецензию на «Дамский альбом» можно воспринимать как своего рода создание контекста для попытки реактуализации Боратынского, которая произойдет в № 10 «Современника» того же, 1854, года (см.: Бодрова, Велижев 2009: 119-147).

Таким образом, мы можем полагать, что рецензия Некрасова, в которой создается интересный литературный контекст, в том числе актуализирующий наследие Боратынского для современной эпохи, встраивается в ряд статей, посвященных второстепенным поэтам и является одной из первых попыток изменить сложившееся отношение к поэту пушкинской поры.

\section{БИБЛИОГРАФИЯ}

Альми И. Л. 1961. Элегии Е. А. Баратынского 1819-1822. - Ленинградский государственный педагогический институт им. А. И. Герцена: Ученые записки. Т. 219 (Вопросы истории русской литературы). Л.: [б. и.].

Анненков П. В. 1989. Литературные воспоминания. М.: Правда.

Баратынский Е. А. 1936. Полн. собр. стихотворений: В 2-х тт. / Ред., комментарии и биографическая ст. Е. Купреяновой, И. Медведевой. Т. 1. М., Л.: Советский писатель.

Белинский В. Г. 1953-1959. Полн. собр. соч.: В 13-ти тт. М.: Издательство Академии наук СССР.

Бенедиктов В. Г. 1939. Стихотворения / Вступительная ст., ред. и примечания Л. Я. Гинзбург. Л.: Советский писатель. 
Березкин А. М. 2008. Авторские построения поэтических сборников Некрасова. - Некрасовский сборник. [Вып.] XIV. СПб.: Наука.

Бодрова А., Велижев М. 2009. И. С. Тургенев - издатель Баратынского, или русские второстепенные поэты в 1854 г. - Тыняновский сборник. Вып. 13: Двенадцатые, тринадцатые, четырнадцатые Тыняновские чтения. М.: Водолей. С. 119-147.

Боратынский Е. А. 2002. Полн. собр. соч. и писем. Т. 2. Ч. 1 / Ред. О. В. Голубева, А. Р. Зарецкий, А. М. Песков. М.: Языки славянской культуры.

Вдовин А. 2007. Из биографического комментария к «гринвальдским» стихотворениям Н. А. Добролюбова. - Озерная текстология. Труды IV летней школы на Карельском перешейке по текстологии и источниковедению русской литературы. Поселок Поляны (Уусикирко) Ленинградской области: Петербургский институт иудаики. С. 74-88.

Венгеров С. А. 1904. Примечания. - Белинский В. Г. Полн. собр. соч.: В 12 ти тт. / Под ред. и с примечаниями С. А. Венгерова. T. VII. СПб.: Типография „Общественная польза“.

Винокур Г. О. 2002. Баратынский и символисты / Републикация, предисловие и примечания С. Г. Бочарова. - К 200-летию Боратынского: Сборник материалов научной конференции, состоявшейся 21-23 февраля 2000 г. М.: ИМЛИ РАН.

Гельфонд М. М. 2012. «Читателя найду в потомстве я...»: Боратынский и поэты ХХ века. М.: Биосфера.

Герцен А. И. 1954-1965. Полн. собр. соч.: В 30-ти тт. М.: Издательство Академии наук СССР.

Гинзбург Л. Я. 1997. О лирике. М.: Интрада.

Гоголь Н. В. 1952. В чем же наконец существо русской поэзии и в чем ее особенность (1846). - Гоголь Н. В. Полн. собр. соч.: В 14-ти тт. Т. 8. М.; Л.: Издательство Академии наук СССР.

Дамский альбом. 1854. М.: Издание книгопродавца К. Круга.

Дружинин А. В. 1987. Стихотворения Н. Некрасова. - Некрасов Н. А. Стихотворения 1856 / Изд. подготовила И. И. Подольская. М.: Наука.

Иванов-Разумник Р. В. 1916. Поэзия бестрагичного и трагического (Белинский о Майкове и Баратынском). - Иванов-Разумник Р. В. Сочинения. Т. V. Пг.: Прометей. С. 170-176.

Летопись жизни Н. А. Некрасова. 2006. В 3-х тт. Т. 1. СПб.: Наука.

Литературное наследство 1949. Т. 53/54: Н. А. Некрасов. Кн. III. М.: Издательство Академии наук СССР. 
Литературное наследство 1950. Т. 56: В. Г. Белинский. Кн. II. М.: Издательство Академии наук СССР.

Мельгунов Б. В. 1980. Из материалов к декабристской теме в архиве Некрасова. - Некрасовский сборник. [Вып.] VII. Л.: Наука.

Некрасов Н. А. 1981-2001. Полн. собр. соч. и писем: В 15-ти тт. Л. - СПб.: Наука.

Некрасов Н. А. 1987. Стихотворения 1856 / Изд. подготовила И. И. Подольская. М.: Наука.

Отечественные записки 1854. T. XCIII. Отд. IV (Журналистика). СПб.: В типографии Королева и К․

Паперно И. 1996. Семиотика поведения: Николай Чернышевский - человек эпохи реализма. М.: Новое литературное обозрение.

Панаева А. Я. 1986. Воспоминания. М.: Правда.

Пушкин А. С. 1937. Полн. собр. соч.: В 16-ти тт. Т. 13: Переписка. 1815-1827. М.; Л.: Издательство Академии наук СССР.

Семенко И. М. 1970. Поэты пушкинской поры. М.: Художественная литература.

Софийская М. Ю. 2010. Некрасовский семинар и первые некрасовские чтения в Пушкинском Доме. - Русская литература. № 1. С. 256-268.

Степина М. Ю. Некрасова Зинаида Николаевна. - Энциклопедия «Некрасов и его окружение». СПб.: Наука (в печати).

Щукин В. Г. 2002. Блеск и нищета «позитивной эротологии» (к концепции любви у Н. Г. Чернышевского). - Вопросы философии. № 1. С. 140-150. 